
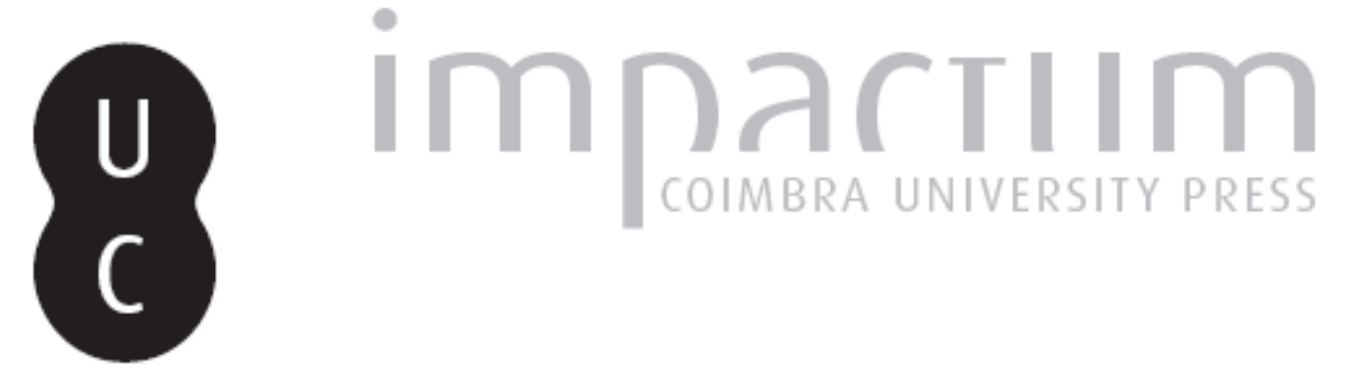

\title{
Building community through a digital literature archive: the case of Ciberia Project
}

Autor(es): $\quad$ Goicoechea, María; Sánchez, Laura

Publicado por: Centro de Literatura Portuguesa; Imprensa da Universidade de Coimbra

URL persistente:

URI:http://hdl.handle.net/10316.2/39099

DOI:

DOI:http://dx.doi.org/10.14195/2182-8830_4-2_5

Accessed : $\quad$ 26-Apr-2023 09:38:34

A navegação consulta e descarregamento dos títulos inseridos nas Bibliotecas Digitais UC Digitalis, UC Pombalina e UC Impactum, pressupõem a aceitação plena e sem reservas dos Termos e Condições de Uso destas Bibliotecas Digitais, disponíveis em https://digitalis.uc.pt/pt-pt/termos.

Conforme exposto nos referidos Termos e Condições de Uso, o descarregamento de títulos de acesso restrito requer uma licença válida de autorização devendo o utilizador aceder ao(s) documento(s) a partir de um endereço de IP da instituição detentora da supramencionada licença.

Ao utilizador é apenas permitido o descarregamento para uso pessoal, pelo que o emprego do(s) título(s) descarregado(s) para outro fim, designadamente comercial, carece de autorização do respetivo autor ou editor da obra.

Na medida em que todas as obras da UC Digitalis se encontram protegidas pelo Código do Direito de Autor e Direitos Conexos e demais legislação aplicável, toda a cópia, parcial ou total, deste documento, nos casos em que é legalmente admitida, deverá conter ou fazer-se acompanhar por este aviso. 

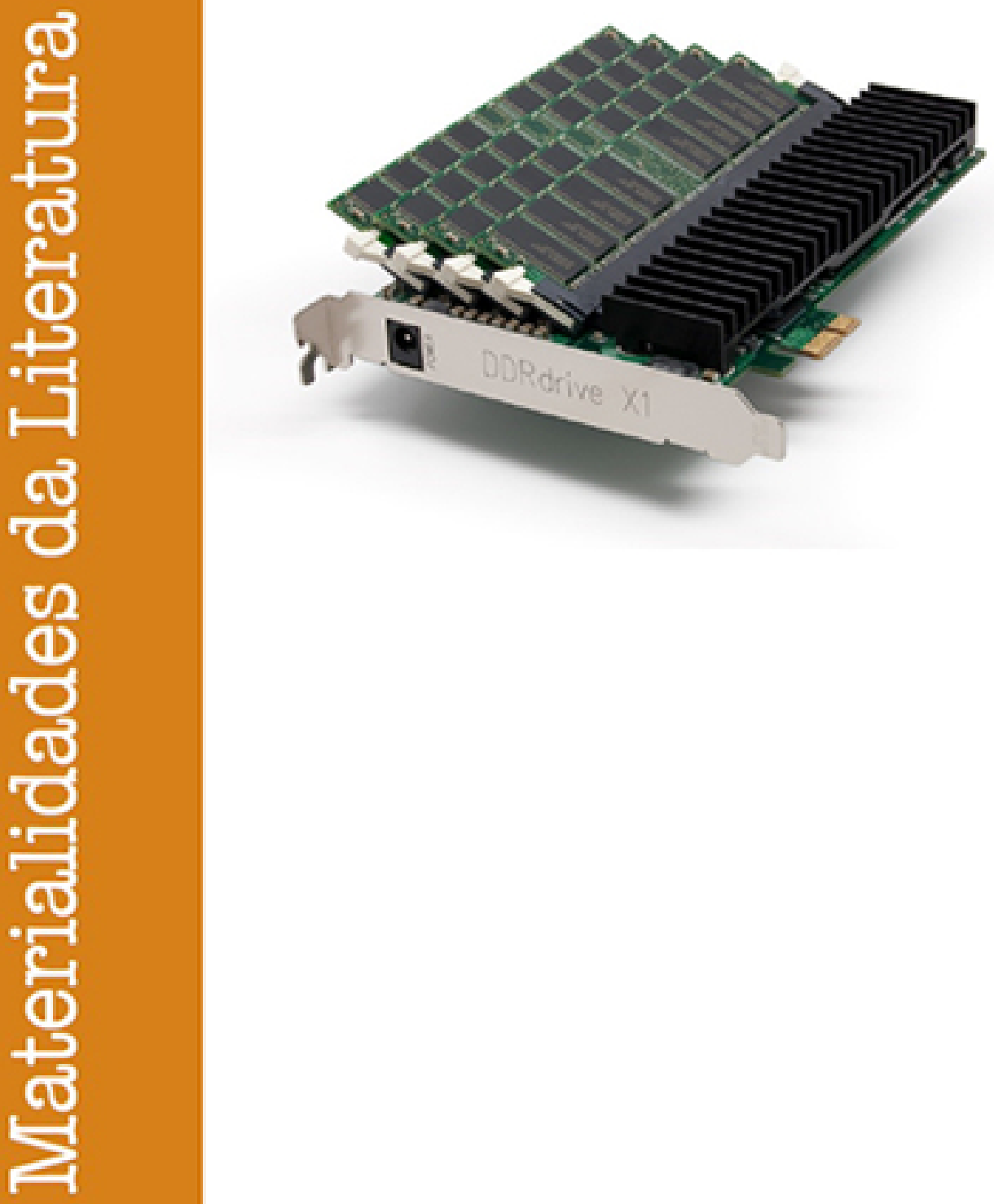

Vol. 4.2 (2016) ISSN 2182-8830

'Estudos Literários Digitais 2'

Manuel Portela e António Rito Silva (orgs.) 


\title{
Building Community through a Digital Literature Archive: The Case of Ciberia Project MARÍA GOICOECHEA
}

\author{
Complutense University of Madrid \\ LAURA SÁNCHEZ \\ Complutense University of Madrid
}

\begin{abstract}
Ciberia Project has emerged around the creation of Ciberia, a digital archive dedicated to digital literature in Spanish, with the purpose of making its contents more widely shared and fostering community building around digital literature. This project intends to function as a platform for a community interested and/or specialized in new creative forms of literary publishing, using the Ciberia database as the confluence point and origin of collective interaction, creation and reflection on digital literature and its ramifications in the field of literary publishing. This paper provides a description of the digital library Ciberia, and its spin-off, the web platform Ciberia Project, offering a detailed account of their structure and potentialities. Keywords: Spanish digital literature; social networking; digital archives; digital publishing; OdA; CLAVY.
\end{abstract}

Resumo

O Ciberia Project surgiu a partir de Ciberia, um arquivo digital dedicado à literatura digital em espanhol, com o objetivo de disseminar o seu conteúdo e contribuir para a criação de uma comunidade em torno da literatura digital. O projeto pretende funcionar como plataforma para uma comunidade interessada e/ou especializada em novas formas criativas de publicação literária, usando a base de dados Ciberia como ponto de confluência e de origem para interação coletiva, criação e reflexão sobre a literatura digital e as suas ramificações no campo da publicação literária. Este artigo apresenta a biblioteca digital Ciberia, e o seu produto derivado, a plataforma web Ciberia Project, descrevendo detalhadamente a sua estrutura e potencialidades. Palavras-chave: literatura digital em espanhol; redes sociais; arquivos digitais; publicação digital; OdA, CLAVY.

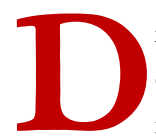

igital Humanities forums are populated by case studies such as this one, i.e. papers based on sharing pioneering experiences with data management systems, aimed at shedding some light on the hard task of constructing ex nibilo, in the digital space, forms of human interaction that were traditionally performed in physical environments or were simply not facilitated. The difficulty very often resides in stepping outside academic environments to reach a wider audience, the type of audience that can make certain projects prosper or collapse under the weight of data trash and obliv- 
ion. Ciberia Project is one of these nascent creatures, which hesitantly gives its first steps in the direction of opening the field of digital literature to readers and writers aloof of the existence of the field, as well as providing a site of encounter for isolated creators and readers already interested in it.

Our first step is to present the Ciberia Project to the digital literature community. The nucleus of Ciberia Project is the archive Ciberia: Biblioteca de literatura digital en español, which is engaged in the creation of a theoretical context for teaching and researching digital literature. The goal of this project is to provide an infrastructure around the archive that will help disseminate research about digital literature, offer a collaborative setting for the creation of digital literature pieces and make digital culture in general more accessible to readers in Spanish. For that purpose, we have created a digital magazine, with an embedded social network, in which we have also integrated the library, as we will describe later. The project also involves the creation of a publishing label that will experiment with new modes of digital editing.

Therefore, the Ciberia Project has evolved from the function of archiving digital literature (Fig. 1) to that of promoting digital literature at other levels (Fig. 2), by defending digital literature as a field inside the Digital Humanities that can offer exciting reading experiences, and become a lab of creative publishing and collaborative experimentation.

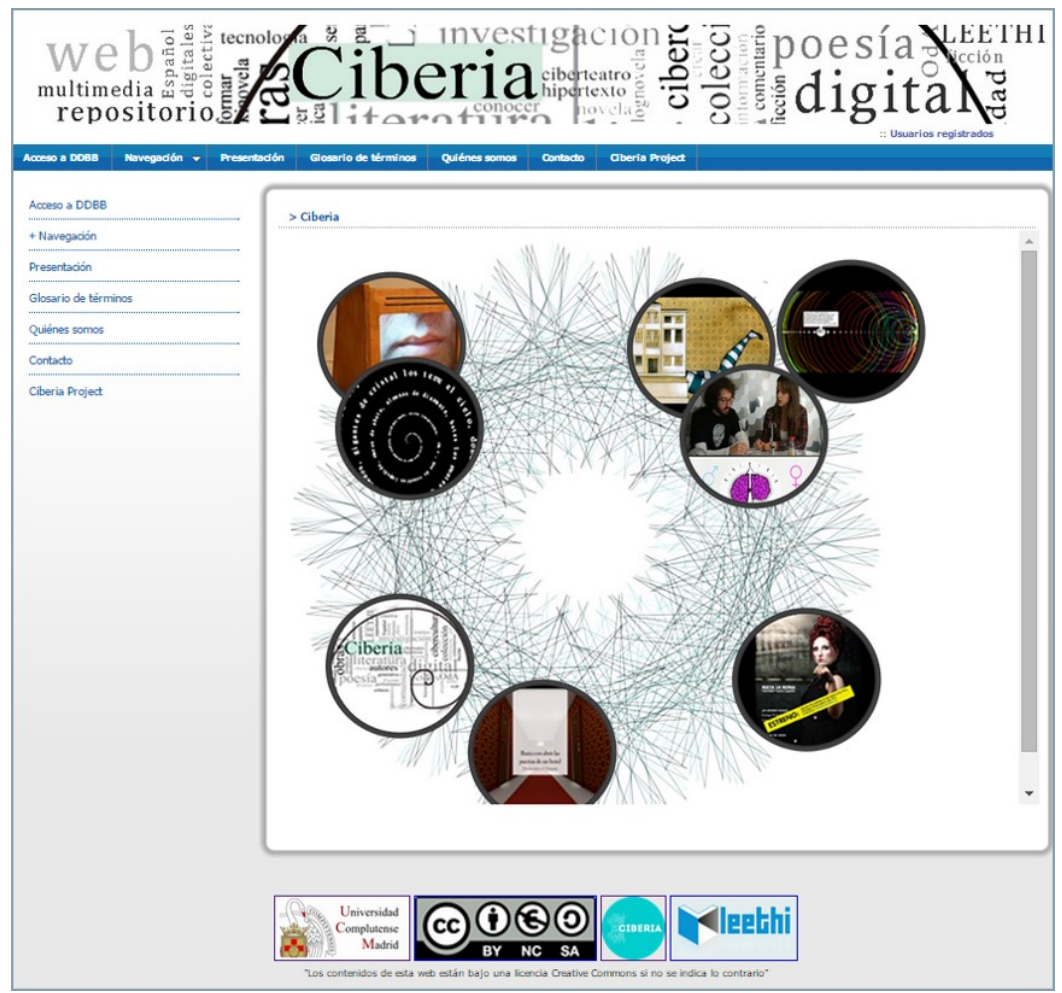

Figure 1. Ciberia Digital Library Homepage. 


CIBERIA $\quad$ PAONECTO. COMUNONO. Quevessonos neticutos $\rho$

\section{CIBERIA}

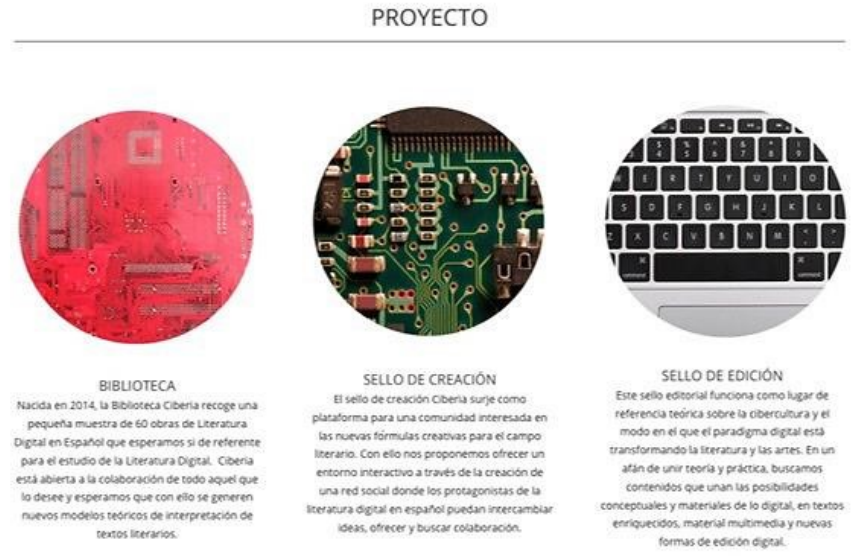

Figure 2. Ciberia Project Homepage.

Let us start by describing the digital archive. Ciberia arises from the need to make digital literature in Spanish more visible, report its development, and keep a record of its existence in the wake of inevitable obsolescence. We chose Spanish to complement with philological accuracy the records in wellestablished digital literature archives. We also use Spanish as a virtual boundary with blurred lines, since we are interested in the study of what we call transliteratures: literary works that travel across data stream spaces of exchange and are modified by the different horizons of expectation and reception they encounter in the digital networks. We archive original works in Spanish, but also those that are the product of translation, multilingual and cultural hybrids, since we would like to explore the new possibilities for literary communication offered by digital literature in the context of cyberspace. We use the archiving process as a practical exercise of alternative canon formation, exploring the extent to which the Internet has introduced new literary categories that challenge cartographical nation concepts around which the literary canon is formed: modifying rituals of readings, formulas of production and dissemination, narrative, theatrical and poetic forms. Therefore, Spanish is the point of departure but not of destination, since we are interested in the evolution of the field as a whole.

There are other collections of Spanish Digital Literature. However, we considered that there was still ample space to complement their entries: pio- 
neering collections, such as those of the NT2 ${ }^{1}$, the ELO Directory ${ }^{2}$, and Hermeneia $^{3}$, have relatively few entries in Spanish, which is normal since their scope is international. The Biblioteca Virtual Miguel de Cervantes has a collection of electronic literature in Spanish ${ }^{4}$, but this one only includes twenty-two narrative works, leaving electronic poetry outside! As a response to this situation, writers of electronic literature themselves, such as Belén Gache, have felt the need to assemble their own collections ${ }^{5}$. The ELMCIP6 has a growing collection of digital literature in Spanish, in part feeding from the contents of Ciberia, among other databases, artists' webpages, and online magazines dedicated to curating electronic literature. Our aim is to continue enriching this collection through our participation in the CELL consortium ${ }^{7}$, the network that will provide access to many digital literature collections around the globe.

Ciberia's architecture is indebted to many of these sites, from which we have gathered ideas regarding the structuring of information in the reposito-

1 The Directory of the Laboratoire NT2 includes the most extensive collection of Spanish works so far. It has registered a total number of 219 entries in Spanish (May $24,2016)$, but these also include portals, webpages, projects, etc. dedicated to digital art in general. The artistic works in Spanish are 181, including works that have just a few words of Spanish in them, or include a Spanish translation provided by free online translation software. Only 15 works have enriched cards, which provide detailed data and descriptions. The great advantage of this directory is that it is regularly updated and covers a wide variety of works, in its detriment we can cite the lack of specificity or adherence to a detailed taxonomy of most of its entries, which forces the researcher to spend a considerable amount of time filtering its data (http://nt2.uqam.ca/fr/search/site/?fo $05 \mathrm{~B} 0 \% 5 \mathrm{D}=$ type $\% 3$ Arepertoire\&retainfilters $=1$ ).

${ }^{2}$ The Electronic Literature Directory (ELD) can be found at: http:/ / directory.eliterature.org/ ${ }^{3}$ Hermeneia's Anthology of Digital Literature can be found at:

http: / $/$ www2.hermeneia.net $/$ index.php $\% 3$ foption $=$ com_content\&view $=$ article\&id $=$ 1953\&Itemid $=314$.

${ }^{4}$ The Collection of Spanish Electronic Literature of the Cervantes Virtual Library can be found at: http://www.cervantesvirtual.com/bib/portal/literaturaelectronica/.

${ }^{5}$ Belén Gache has created a webpage titled "Lunar Society", whose future objective is to become an "expanded literature" database, but for the moment it provides an inventory of Gustavo Romano's and her own work. Its most attractive contribution is the Blog of the Lunar Society, aimed at providing the interpretative context for new models of expanded literature as it leads the reader back to relevant artistic antecedents in conceptual writing, visual poetry, linguistic games, language and machines, etc. http://sociedadlunar.org/index.html.

${ }^{6}$ Electronic Literature as a Model of Creativity and Innovation in Practice (ELMCIP) is a collaborative research project funded by Humanities in the European Research Area (HERA). Its webpage can be found at: http:// elmcip.net/.

7 The Consortium on Electronic Literature (CELL) is an open access resource offering centralized access to literary databases and archives with a focus on electronic literature. CELL was founded by the Electronic Literature Organization (ELO). It currently includes ten members and is designed to allow for the integration of many more. The first phase of CELL's project-a search engine that harvests and aggregates records from across five partner databases (ELMCIP, ELD, NT2, CIBERIA, PO-EX)—was funded by an NEH Digital Humanities Start-Up Grant and developed at the NT2 Lab in Montreal. See at: http://cellproject.net/. 
ry. Following the ELMCIP's example, for instance, we have created a database where we can upload all kinds of materials and documents that can be used to integrate e-literature in our curricula: critical works, student works, organized constellations of entries around a topic, etc.

At this point, Ciberia is a small collection of electronic literature works in Spanish created by two interdisciplinary research teams from the Complutense University of Madrid: LEETHI ${ }^{8}$ (European Literatures from Text to Hypermedia) and ILSA9 (Implementation of Language-Driven Software and Applications). LEETHI has provided the content for this collection, which has been constructed using OdA 2.0., a type of data management software developed by ILSA.

\section{About OdA: A Data Management System in the Cloud}

Thanks to the collaboration between these two groups, LEETHI and ILSA, the Ciberia project can engage in experimentation at different levels. Firstly, we are testing with the archiving process itself, which we are carrying out in OdA 2.0, a data management system for the creation of learning objects repositories collaboratively on the Web.

OdA allows different researchers to work simultaneously on the database; they can not only introduce new objects but they can also modify the data model. This entourage allows researches in distant locations to work collaboratively and create taxonomies in an inductive rather than deductive manner. We can adapt our data model to fit new genres, integrate new categories and relationships. Recently, we have also modified our data model to adapt to the new taxonomies proposed by the CELL project, which includes four vocabulary lists for the following distinguishing features: publication type/s (channels of dissemination, for example, a computer application or a performance), procedural modalities (the type of interaction between work and user, for example, the different types of navigation a work allows, or if the user can insert data), mechanisms (any device that provides input or output to a computer, for example a camera or a keyboard), and formats (the different mediatic elements or codes incorporated into the work, such as audio, text, video, etc.). As stated in CELL's webpage, the main purpose is to

\footnotetext{
8 LEETHI research activity has focused on the transformations of literary reading and writing rituals caused by digital technology and globalization, with a strong emphasis on integrating theoretical and pedagogical perspectives, since it is formed by members of the Philology and Education Faculties.

9 ILSA is an interdisciplinary group that brings together researchers from different centers and Departments, including the Department of Software Engineering and Artificial Intelligence, and Computing Systems and Computation, interested in developing language-driven software for e-learning applications and the Digital Humanities.
} 
provide a representation of common categories used in the study of digital literature:

All the projects regrouped under the CELL project address electronic literature works from distinctive points of view. Each built a classification system for the works in their database through taxonomies that are specific to their research orientation. The objective of the CELL project is to reunite all those orientations to come up with a general and common classification that could reflect the current state of research in the field.

This common classification is based on the most "objective" categories that could be used to describe a digital literature work, but it also impinges directly on the way the work is analyzed, emphasizing its material, technological nature over its discursive and interpretive condition. In Ciberia, we have integrated these categories into an enriched card that includes other, more subjective, fields, such as "themes", "genres", "critical appraisal", etc.

From the technological perspective, ${ }^{10}$ we have approached the creation of the collection from a different angle than other repositories. The most important change is that the repository can be modified by several people at the same time, in all the states of the repository progress. The system regenerates the navigation hierarchy and search form to adapt to the new collection's structure. This element allows Ciberia to be a live project that can be expanded or modified for several years.

The new version CLAVY, which now currently works behind OdA's shell, is what is allowing us to export our data to the CELL project, but it can also be used to import data from different databases and file metadata containers. Thanks to CLAVY, we have managed to integrate Ciberia inside the CELL project, which will hopefully help to make more visible the peculiarities of Hispanic digital literature and its modes of creation and reception.

\section{In Search of a Data Model}

In order to design the structure of the database and its data cards, we have made an analysis of the main digital literature repositories, such as the Canadian Laboratoire NT2, the ELO Directory, or the ELMCIP archive, adopting from each the features we find most useful:

${ }^{10}$ For those interested in the technical details: OdA 2.0 is a web system with PHP language and MySQL database for server, and HTML-CSS for client. Actually there is a new project that extends OdA's work. This new project, called Clavy, is a RIA (Rich Internet Application) which uses Google's GWT API to create a new interface and provide tools that allow the integration in a modern Glassfish Java server (which can use php also) and a MySQL database mapped by JPA technology. 
1. We found the NT2 taxonomy of tags very didactic so we have adapted most of its categories.

2. We thought that such a taxonomy opens many questions and that the ELO collection keyword glossary was an efficient way to guide visitors through the collection.

3. We also found very useful ELMCIP's idea of allowing researchers to upload their own content, and create personal pages inside the repository.

In the article "A Survey of Electronic Literature Collections" (Pablo and Goicoechea, 2014) we synthesize our evaluation of digital literature archives, describing their characteristics and functions, analyzing the descriptors used and the way information can be accessed. In our conclusions, we advocate a database structure which is flexible and can produce a dynamic archiving model as texts are registered and collected, so that the set of tags used to describe them can expand as new texts make new tags necessary. Since the organization of tags into ever more complex taxonomies seems inevitable, if we want to provide an accurate description of the knowledge accumulation with respect to the field's richness, we need a flexible system that favors collaboration among different researchers. This study has allowed us to appreciate the malleability of a system such as OdA, and select the best practices among archives with a long experience and a great number of entries.

\section{Ciberia's Administration Panel}

The administration panel of Ciberia can be accessed from the main page by administrators to maintain the website, add new digital objects and modify the data model. The system is extremely flexible. These are the type of operations that it allows you to do:

- You can create new fields and new tags every time we need them, eliminate them, and change their nature (open text fields, controlled vocabulary, etc.) or their location inside the taxonomy. You can also decide which fields are going to appear in the navigation menu (Fig.4).

- If we change the location of a field, everything that was classified using that field moves with it.

- You can lose data if you eliminate fields, but you can eliminate parent directories without losing data of the children directories, which will move to the parent level. 


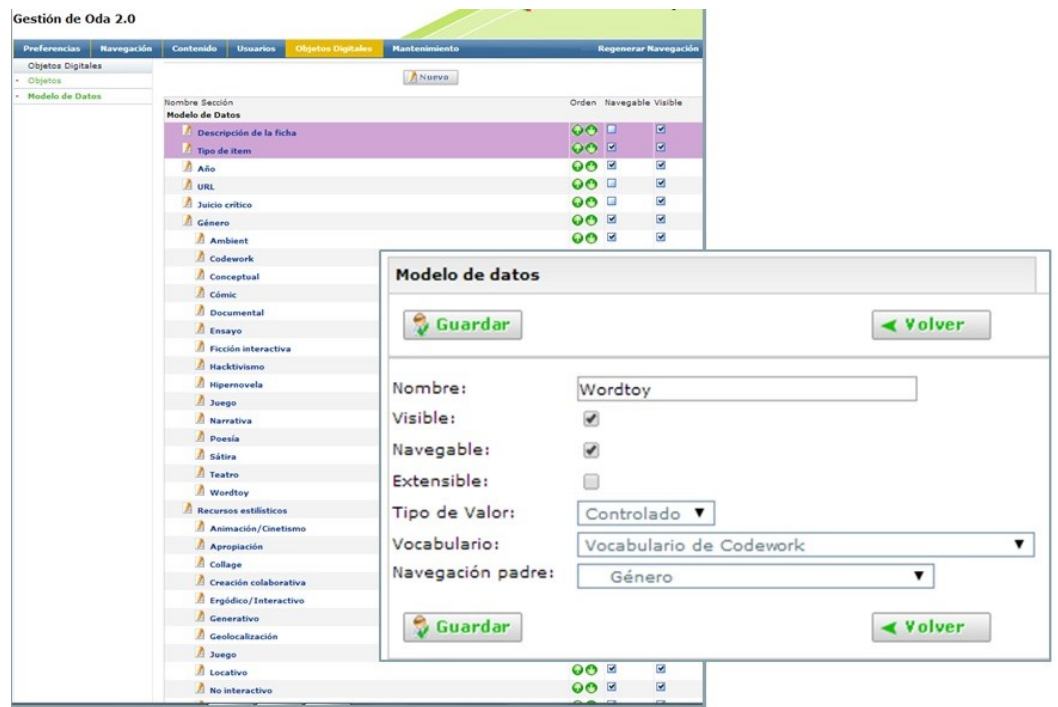

Figure 3. Ciberia's Administration Panel.

\section{Navigation}

The search engine is a replica of the data model, so it allows you to filter data with a high-degree of complexity. ${ }^{11}$ At present, the archive offers the following search fields for navigation: Types of items: work/author; Year; Genre; Rhetorical Devices; Theme; Format; Languages; Computer programs; Collective name; Title; More tags; Modes of reading; and Publication type. A future addition will include a simple search field to explore the whole database contents, imitating a Google search. However, we feel it is important to preserve the taxonomy as a possible search criterion or mode of entry.

${ }^{11}$ For a more detailed account of the inner structure of Ciberia you can read "The Ciberia Project: An Experiment in Digital Hermeneutics" (Goicoechea, 2015). 

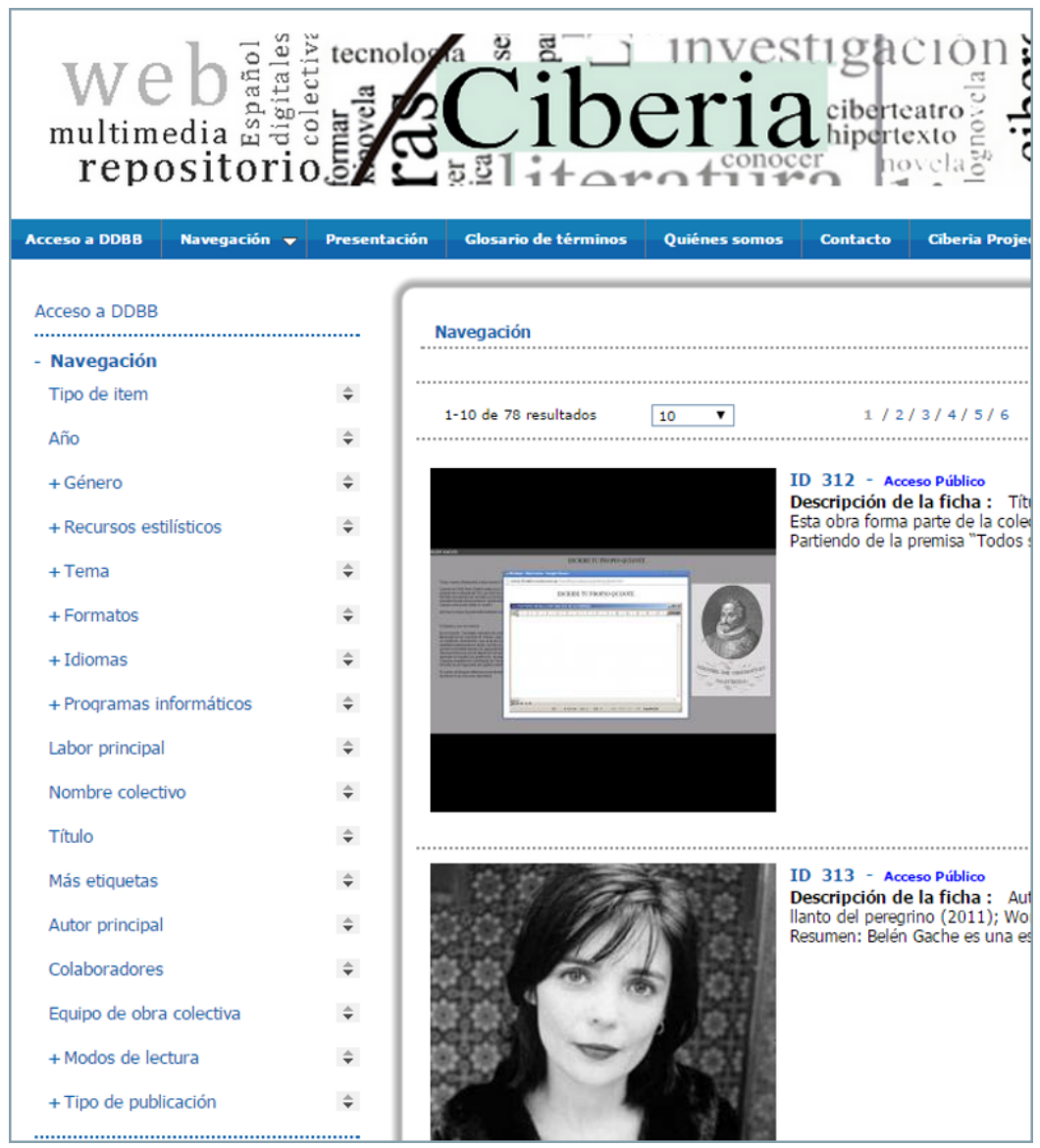

Figure 4. Ciberia's navigation menu.

\section{Example of work card: Simple card, Resources card and Enriched card}

Ciberia's didactic function relies mainly on the critical and contextual information that emerges with each work, giving prominence to the way in which the taxonomy and distribution of information concretize the very structure of the library. Information is distributed according to the type of item it relates to (work, author, event...), and each item is described by three types of cards (simplified card, resources card, and enriched card). This distribution is inspired by the triples of the semantic web's Resource Description Framework (RDF), which aims at creating standards of metadata that can help retrieve, share and reuse data across different applications, networks, databases, etc. The simple card contains the most relevant information to identify the item, in the case of electronic literature works: their title, URL, year of publication, brief description, language, genre, format, etc. The resources card shows the relations among different items inside the library (as it connects the work 
with its creator and vice versa, and other related works), and beyond (linking the work card, for example, with critical essays about the piece, reading statements, URLs, images, videos, articles, interviews, etc.). And finally, the enriched card, which contains more detailed and specific information, such as reading instructions, critical evaluation, the awards received by the piece or the venues in which it has been presented. This card also collects information about the creator, the date of publication, and the status of the entry.

Our aim is to attach as much information about a work as we can, since we do not have the resources to archive the piece itself and secure its permanence. Thus we act as ephemera librarians that try to catalogue a constellation of responses around literary manifestations, which might in the future serve researches to reconstruct the evolution of the field. In the resources sections we provide links to online resources about the work and we want also to upload videos of reading sessions (especially of works under commercial license), lesson plans using that work, critical essays, etc. Among the features we would like to add in this section are specific instances of the work, both as screen captures or videos, in which their most distinctive characteristics can be observed. If a work has been tagged with certain tags that define it in terms of style or rhetorical devices, it would be very useful for researchers to be able to search for examples of 'retro-futurism', 'contrapuntal sound' or of a particular rhetorical link use, and be able to access excerpts of different works where that specific device is used or that style becomes apparent.

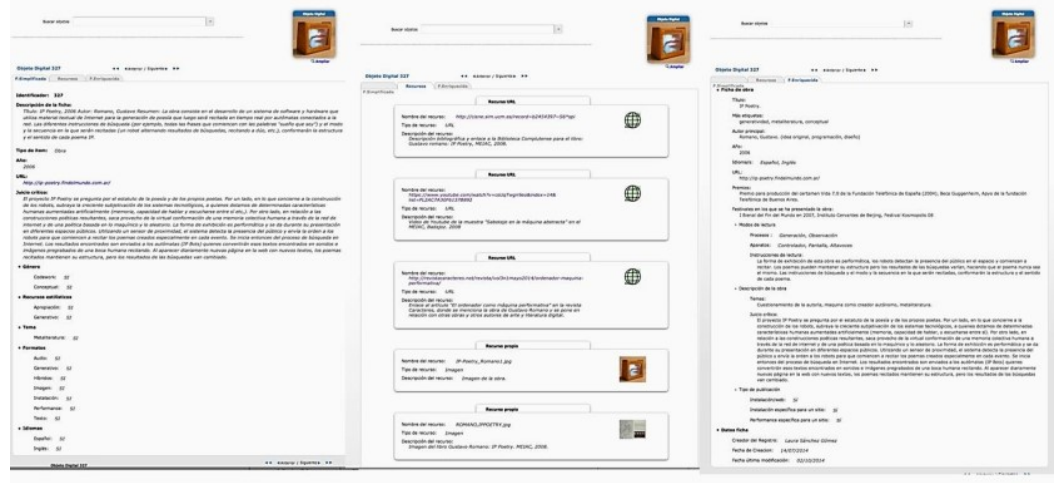

Figure 5. Example of simple card, resources card, and enriched card.

\section{Ciberia's Homepage}

Our main page will change its appearance to feature novelties or specially enriched material. At present, we have highlighted, for example, Domenico 
Chiappe's new work, Hotel Minotauro (2015), the theatrical performance Mata la reina (2011) by the collective Yoctobit, and the interactive short movie Mindstorming (2010), among others. We wanted to use this layout as an invitation for readers to explore the archive, showcasing the great variety of proposals we have included under the heading of Digital Literature. Mata la reina, for example, has compelled us to include "playable drama" as a new genre inside the taxonomy. This hybrid dramatic genre, midway between a collaborative videogame and a play, experiments with the use of technology as an integral part of the performance and reflects upon the modes of interaction it fosters. This play, for instance, introduces a cyborgic, tyrannical, yet absent character, the Queen, who resides as an artificial intelligence inside the computer, and whose power a few real actors incite the audience to overthrow. Another fringe piece we have chosen to highlight is the interactive short movie Mindstorming (both in English and Spanish versions), which provides the same visuals for the three different sketches the reader/spectator can choose from in its webpage. The sketches represent three moments: the first meeting of a couple who has met chatting on the web, their breakup, and their last encounter. You do not hear their voices but you can access the thoughts of the man or the woman by moving the arrow left or right. As it happens with all of the collection's pieces, from these examples emanates a new cybercultural sensitivity, which provides them with a family resemblance, also shared by more 'canonical' pieces of electronic literature, such as hypertext fiction or chatbot drama. They also manifest the seminal role collective pieces have played in the transformation of authorial identities, a tendency with a long tradition among Spanish creators.

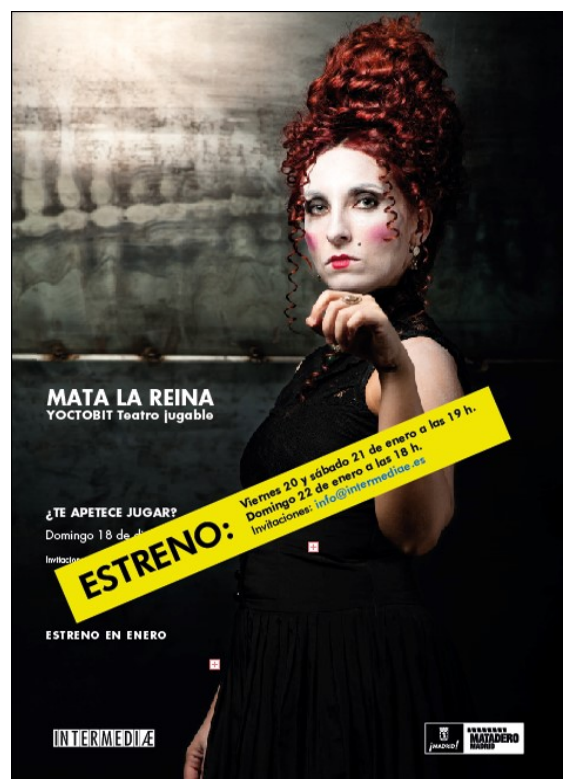

Figure 6. Mata la reina (2011) by Yoctobit. 


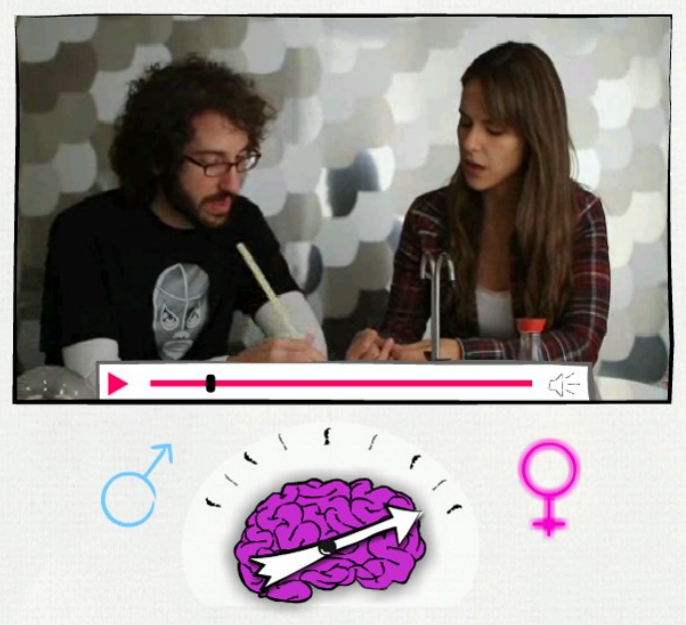

Figure 7. Mindstorming (2010) by Miguel Campos.

\section{Ciberia project}

Ciberia Project is born with Ciberia digital library as its nucleus and main engine. But now the archive has an infrastructure that allows greater interaction among participants of the digital literature community, who can contribute with their posts, articles and tags to the information provided by the library cards. Participants of the community can also find an open environment in which to collaborate, form groups and discuss their projects.

Ciberia Project is articulated around three main sections, clearly differentiated but in continuous dialogue: the library of digital literature and the article section, the digital creation label based on the collaborative work of the community and the promotion of its works, and a publishing label focused on electronic literature and cyberculture theories.

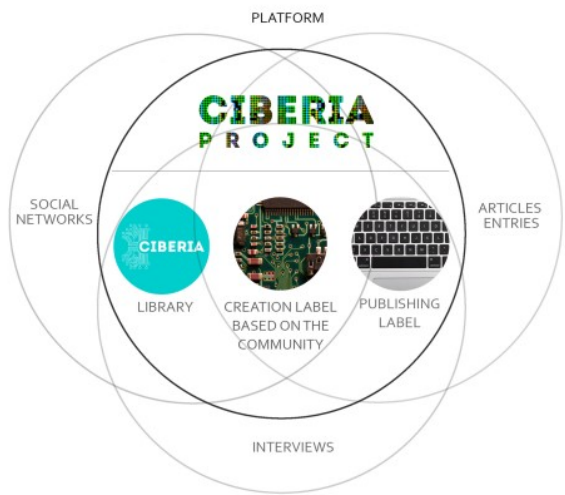

Figure 8. Different sections in Ciberia Project. 
Now we are going to describe these sections and how they function inside the platform in more detail.

\section{Ciberia: A Digital Library}

The digital library, which we have already described, is housed in the University Complutense's servers, and Ciberia Project functions as its entrance hall or portal, offering a more interactive and participatory environment from which the substance of the library can nourish itself. The blog functions as a magazine and a place of encounter (since it is open to anybody who wishes to participate). The blog's contents can help expand the digital library elementss with specialized articles, interviews, news and events about digital literature, art, and culture. The blog also facilitates the distribution of information through social networks and the tagging of content in a free and organic manner by the users. Moreover, the articles that keep a direct relation with the works we have referenced in Ciberia library will be linked to the work's resources data card in the library. In this manner, the blog functions as a social network from which we can share and discuss ideas, making direct reference to the library, its works and authors.

We show below four examples of the blog's entries (Fig. 9. clockwise): "Barcodes: Poetry as encounter and rupture", an unpublished reflection by the author and creator Tina Escaja regarding her contributions to the collective exhibition in Malpartida (Cáceres, Spain); an article about the presence of digital art in Madrid's contemporary art annual fair ARCO 2015; a review of Claudia Kozak's book Argentinian Technopoetics. A Soft Archive of Art and Technology; and finally, an interview with Doménico Chiappe. The link to the interview can be found in Doménico's author card and in "Hotel Minotauro"'s work card, generating in this manner a dialogue between the different parts of the project that enriches and expands its horizons and research possibilities. 
CIBERIA

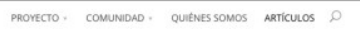

\section{ARTÍCULOS}

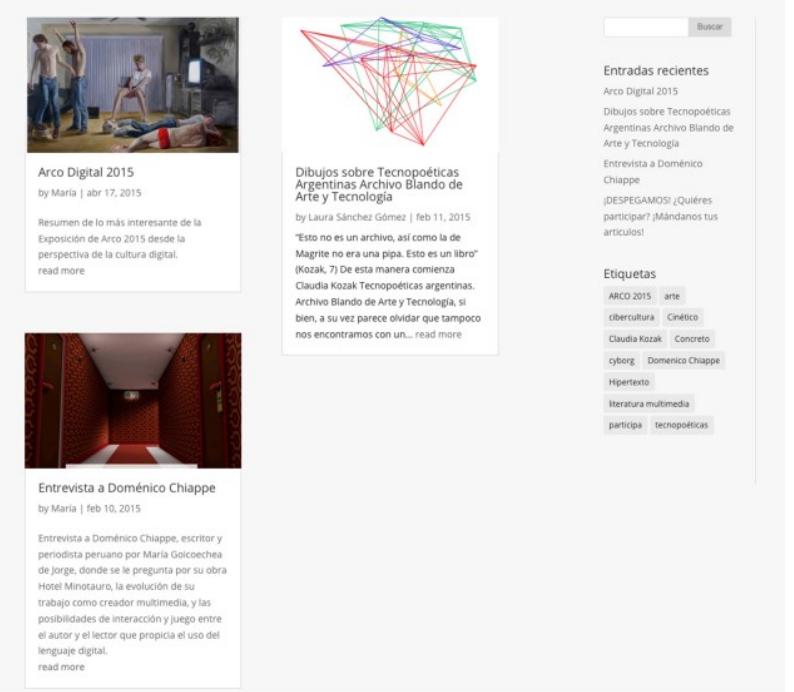

Figure 9. Ciberia Project's Article section.

\section{Digital Creation Label: Building Community}

The digital creation label functions as a community platform, an internal social network that can be used as a place of encounter for anybody interested in digital creation, electronic literature and cyberculture: writers, design artists, illustrators, musicians, video artists, programmers, etc. Especially for those interested in collaborative and interdisciplinary work, two of the main protagonists in digital literature creation. The Ciberia Project's community hopes to function as a free network, it is a modest proposal that does not aim at replicating impressive initiatives such as the ELMCIP's, whose scope is closer to a collective encyclopedia developed by specialists of digital literature. We are inspired by projects such as Born Magazine: Art and Literature Collaboration, in relation to their understanding of the social tissue as the central axis around which the creative experiences it houses germinate.

Ciberia Project's social network is dedicated to digital creation, thus the personal profiles are designed so that users can directly offer services and skills, demand collaboration, and show their previous works. The network facilitates contacting people, making friends and creating workgroups specialized in genres or subjects. There is also an activity board to follow novelties and stay up to date. In this manner we hope that the community can become 
an engine for creative experimentation, as well as a collaborative laboratory where new forms of digital creation and electronic textuality emerge. Our label will house the resulting products and will provide the necessary mechanisms for their exhibition, diffusion and download depending on the licenses established by their authors.

The profile structure is designed in a simple way to facilitate the information search. For this purpose, the two main fields are those of "I offer..." (the skills you put at the service of the community) and "I need..." (the type of collaboration you are searching for). You also have a very brief card with your name, profession, skills, and short biography. There is also the possibility to provide links to your previous works or other personal webpages, as well as introducing images from other sites to construct the field of personal activity, which can become a more dynamic wall to present yourself. The search function permits making any field inside the profile "searchable".

We understand that our function as "revitalizers" and "curators" of the field of electronic literature is that of triggering interaction and collaboration among its members according to their interests and needs, to establish awards and organize fairs and exhibitions of electronic literature, as well as new forms of creative digital publishing. For example, next year (2016) we will be organizing our first Ciberia Prize for Children's Electronic Literature.

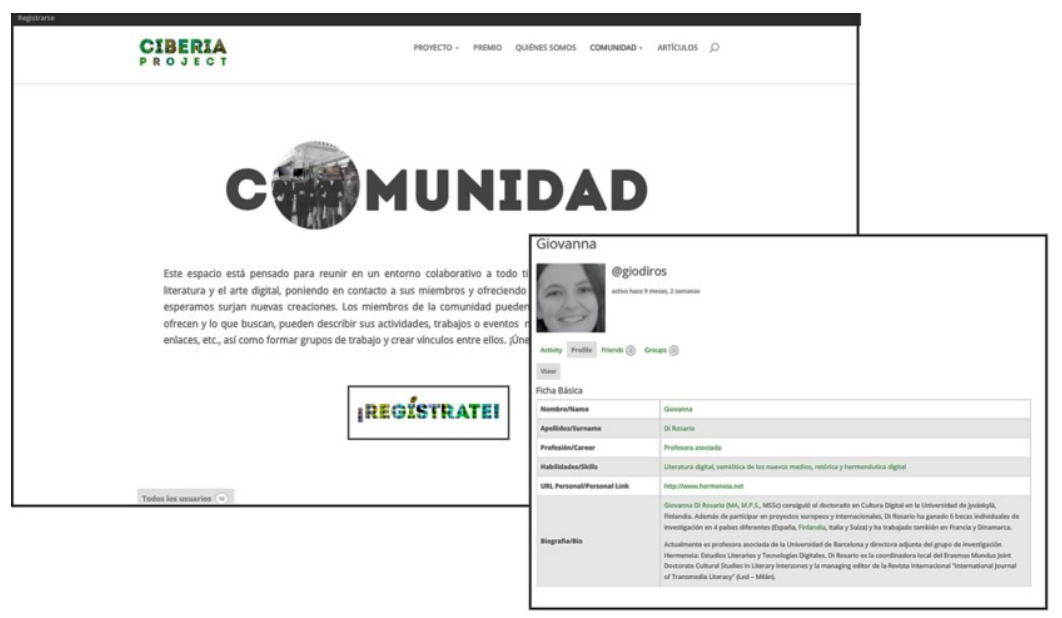

Figure 10. Ciberia Project's registration page and user profile card.

\section{Publishing Label}

The publishing label hopes to promote and explore new digital publishing and editorial models. We want to explore electronic literature as a field of digital publishing experimentation, since we consider that this field contains the seed for the future standards of the publishing industry. We believe that it 
is necessary to continue searching for new publishing formulas that exploit to the full the possibilities opened up by digital technologies. Through our research, we would like to integrate the type of reading economy demanded by the content of cyberculture's theoretical works (interactive, connected, metareflexive, creative) with the digital possibilities offered by electronic textuality. These new sensitivities are made explicit by the creative practices germinating in the creation label. We would, therefore, explore the type of contributions that electronic literature, as a site of literary and technological experimentation, can offer to the quest for standardized models of digital publishing that the editorial industry is undertaking. From this perspective, we would like to test the limits of standard formats, such as EPUB3, for interactive storytelling, for example, and offer alternative web design solutions to proprietary software. As John W. Maxwell acknowledges:

we are now in the midst of a large scale effort on the part of the publishing industry (broadly enough conceived as to include Amazon.com) to allow publishing as we have known it to engage with the digital age -but in ways which are not so fundamentally threatening as worldwide, ubiquitous, networked digital media might be. It is a very particular casting of digital media in a role within an older, established tradition of communications and authority -a manoeuvre in what Clifford Lynch over a decade ago called "the battle to define the future of the book." (30-31)

As a partial solution to the industry's imperious maneuvering, we feel we need to return to a do-it-yourself credo, which is the spirit that has guided us since the inception of the digital library Ciberia, and test for ourselves the problems of interoperability, accessibility, and layout generated by each format.

We would also like to boost Spanish translations of theoretical key texts of cyberculture and digital literature: summarizing contents, adapting texts to reading by levels (using "stretchtext"), making informational pills, etc., with the intention of disseminating the content of digital narratives and discourses, which is the context where digital literature makes sense.

So far we have divided the project into three different sections (archive+blog, creation label and publishing label) because each deals with its own concerns and constraints, though we are interested in studying the dialogue between the parts. For example, the creation label can foster collaboration among its members and from this encounter we hope new pieces emerge, which could be included in the archive. In the wake of new creative works, new critical texts can be written and included in the article section, and through the publication label we can together explore new models of digital publishing and new channels to obtain visibility, distribution, and commercialization of digital works. 
Some researchers and creators of digital literature believe that digital literature can be the working lab for the development of new editing formulas. But in this quest for a standardized model, the value of literary and critical content is often overridden by the price of platforms and devices. We would like to grant the content a voice and study in depth the kind of display that literary as well as critical or theoretical material requires, keeping an openminded and practical perspective.

There are still many open questions: Is the format restricting the possibilities of digital publishing of textual and multimedia contents? Where will it take us the current medium supremacy over content? What type of business model is being created around electronic publishing and what type of affordances or constraints does it bring with it, and for whom? We are aware of the current battles to establish a digital publishing standard (ePub 3, html5, ad hoc apps), and our research would like to contribute with alternative models that explore to the fullest the possibilities of digital publishing, trying to find a middle position between the radical departure from normative standards that some works of digital literature represent, and the rigidity and closeness that publishing formats like ePUB entail; between the constant devaluation of content in favor of technological artifacts and the stagnant permanence of traditional reading economies.

\section{Conclusions}

To conclude, we could say that the experience of archiving digital literature has shown us the usefulness of finding programming spaces that facilitate collaboration in the creation of data models and that can describe a field that is in permanent change. It has also made us realize the need to share information in ever growing networks, and, for that purpose, we benefit from the use of digital technology as a platform on which to establish an online community that can respond actively to the production of theoretical content and the search for practical models through digital creation.

So far we have presented the digital archive Ciberia, which works as the nucleus of several derivate projects: a social network and a webpage around which a community can interact, and a publishing label focused on electronic literature creation and the dissemination of cyberculture. The aim of its creators is, on the one hand, to collect and give more visibility to the variety of works of digital literature in Spanish. And, on the other hand, to use the digital literature archive Ciberia as the core of a social networking project that will help build a community of readers and creators interested in new media art in general and new forms of literary publication in particular. We hope that this project serves to raise awareness towards the wealth of creativity and experimentation present in digital literature, a type of literature born at the intersection of cyberculture and art, bringing together elements from many 
different disciplines. In short, a laboratory of new formulas for the literary in cyberspace and a field of digitally-born pieces that contain the seeds for the future standards of the publishing industry.

\section{Who is creating Ciberia Project?}

Finally, we would like to add that this project is born, above all, out of two persons who enjoy what they do and believe that ideas and enthusiasm are the engine behind research and development. However, we would not have been able to accomplish anything without the help of a nurturing network of equally passionate researchers. We would like to thank LEETHI, the research group to which we belong for the unconditional support it provides us. And we would also like to give our thanks to the Factoría Cultural and the Germán Sánchez Ruipérez' Foundation for supporting our idea and offering us a space inside the start-up program for emerging publishing projects called EmprendeLibro. This project would not have been possible either without the assistance of computer science researchers from the ILSA research group and financial support from both public and private sectors.

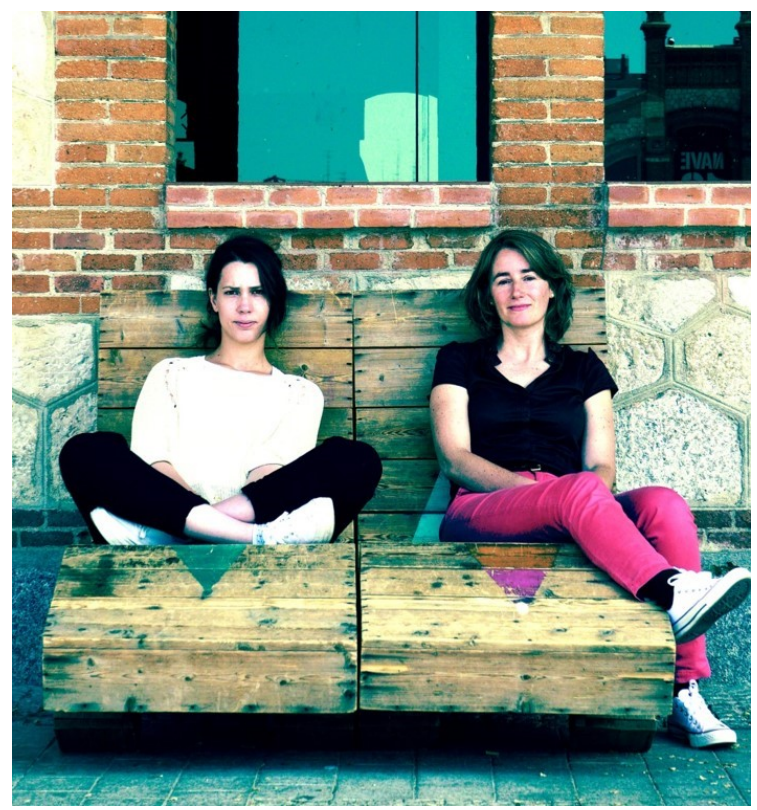

Figure 11. Laura Sánchez and María Goicoechea. 


\section{Acknowledgements}

This research is being funded by the Ministry of Economy of Spain, Project title: "Escritorios Electrónicos para las Literaturas-2", Reference FFI201234666 (2012-2015), IP: Dolores Romero López, and by the banking institution BBVA, Project title: "Modelo unificado de Gestión de Colecciones Digitales con Estructuras Reconfigurables: Aplicación a la Creación de Bibliotecas Digitales Especializadas para Investigación y Docencia”, Reference HUM14_251, José Luis Sierra Rodríguez, Facultad de Informática, UCM. 01/01/201531/12/2016. I Convocatoria de Ayudas a Proyectos de Investigación de la Fundación BBVA.

\section{References}

GOICOECHEA, María (2015). "The Ciberia Project: An Experiment in Digital Hermeneutics." Texto Digital 11.1: 4-20. 01 Jul. 2015. https://periodicos.ufsc.br/index.php/textodigital/article/view/18079288.2015v11n1p4/29767.

MAXWELL, John W. (2013). "E-Book Logic: We Can Do Better.” Papers of The Bibliographical Society of Canada, 51. 1: 29-47. 01 Jul. 2015. http://jps.library.utoronto.ca/index.php/bsc/article/view/20761.

PABLO, Luis, and María Goicoechea (2014). "A Survey of Electronic Literature Collections." CLCWeb: Comparative Literature and Culture 16.5. 01 Jul. 2015. http://dx.doi.org/10.7771/1481-4374.2558.

(C) 2016 María Goicoechea and Laura Sánchez. Licensed under the Creative Commons Attribution-NoncommercialNo Derivative Works 4.0 International (CC BY-NC-ND 4.0). 